\title{
Slum Upgrading: \\ A Challenge as Big as the City of São Paulo, Brazil
}

\author{
Elisabete França \\ Architect; founding director of Studio2E-IdeiasUrbanas; former deputy-secretary, \\ Municipal Social Housing Secretary, City of São Paulo (2005-2012).
}

Eleven million people live in the city of São Paulo, Brazil, 50 percent of them in what is considered "subnormal" housing-squatter settlements, slums, and illegal land subdivisions. They suffer from overcrowding, unhealthy buildings, unsafe environments, lack of basic infrastructure and amenities, and costly public transportation. Elisabete França, São Paulo's deputy secretary for social housing from 2005 to 2012 , discusses the city's successful new approaches in public housing and slum upgrading.

W

hen I started my job as the city of São Paulo's deputy secretary of public housing 1 in 2005 , I faced a major challenge: how to organize the city's social housing policy. To address such a challenge I realized that we had to rely on the lessons from previous experiences from collaborations with international development agencies such as the World Bank, the Inter-American Development Bank, and UN-Habitat. These experiences had mainly taught us the importance of training the permanent technical staff of the public agencies. After all, they are the ones who, over several successive government administrations, keep the programs alive and, in the case of the city of São Paulo's Social Housing Department (SEHAB), know the city's reality and its housing problems.

We had also learned that information management and the access to that information -in a simple and user-friendly wayare what really ensure a democratic leadership of programs and projects proposed by the government. Information transparency keeps away government's patronage, and only easy access to and transparency of information can allow society to participate responsibly in the various forums for democratic debate and participation that our administration transformed into a fundamental part of the construction of the municipal housing policy. Because public policies presuppose choices that in a context of scarce resources can only be made from clear criteria in order to prioritize investments, information systematization is essential.

Two other important decisions adopted in 2005 also mark the production of São Paulo's current housing policy. The first decision was to invest in design quality. Good architecture and

\footnotetext{
${ }^{1}$ The management structure of cities in Brazil includes secretarias or secretaries that are the equivalent to city departments in the U.S. However, as the head of a city's executive branch, once elected a mayor appoints all his secretarios (heads of the secretarias) and controls all management positions that, therefore, generally depend on his political commitments and alliances.
}

urban design, as well as the best of engineering techniques, enabled SEHAB projects to have a bigger impact and become well regarded by the public. Public architecture, in the housing field, is a fundamental element in building the city.

The second important decision was to recognize local cultures and pre-existences, particularly respecting the incremental investments that families living in favelas (slums or squatter settlements) ${ }^{2}$ had made over decades through self- or mutualhelp processes. This led to projects for the upgrading of several favelas and transforming them into normal neighborhoods, integrating them into the formal city and generating great gains in the quality of life for those communities.

The successful public projects and the new housing units built over the past eight years in São Paulo have proved the new housing policy to be a feasible alternative approach to common past practices: cheap cookie-cutter and bureaucratic public housing located in the city outskirts far from jobs and amenities, and lacking environmental and design concerns besides cutting down costs.

\section{Social Housing in Brazil}

Housing production in Brazil has always suffered from the lack of a national housing policy that could reduce the effects of the uneven development and rapid urbanization that started to leave deep marks in the country in the 1950s. ${ }^{3}$ Created in 1964, the National Housing Bank (BNH) and the Housing Financing System (SFH) proved to be unable to meet the ever-increasing

\footnotetext{
${ }^{2}$ In this article the words favela, slum, and squatter settlement are used interchangeably to mean a community occupying land to which it has no legal title, in precarious homes (shacks or self-help built), and lacking basic infrastructure and public services.

${ }^{3}$ For the formation of the contemporary city in Brazil, see Rio, V. and Siembieda, W. (eds) Contemporary Urbanism in Brazil: Beyond Brasilia (Gainesville: University of Florida Press, 2010).
} 


\section{Slum Upgrading-Main Concepts}

Slum upgrading is regarded as an important component of the strategies to fight poverty, because investments made in basic infrastructure and services contribute significantly toward reducing the inequalities faced by the families living in these informal settlements. The investments also have a significant impact on the wellbeing and quality of life of the communities. Slum upgrading became a pivotal part of the housing policy, because it promotes actions that contribute directly to improving the stock of housing solutions accessible to low-income families that otherwise would not be able to access credit and the formal private market.

This process of change in the housing policy models led to the approval of an international action plan centered on social development and the eradication of poverty during the United Nations' Second Conference on Human Settlements (Habitat II) in Istanbul, Turkey, in 1996. This plan was a historical landmark for the setting of the new values and concepts that today form the basic framework of Brazil's public policies, especially housing policies at the federal, state, and municipal levels.

The main purpose of slum upgrading is to overcome shortages of infrastructure, accessibility, and availability of social facilities and public services, as well as the provision of new suitable housing for families whose homes are affected by the public works. The main goal is to respect the existing community and to keep the majority of the families in their locales, assuring the continuity of the investments they have made in building their homes over time.

The second main goal in slum upgrading is the "qualification" of public space; that is, not only to increase the social and recreational quality of public spaces, but also to recognize these spaces as important elements that can promote the physical integration of the community with the neighboring areas and improve their recognition as part of the formal city. Thus, besides solving problems such as sanitation, drainage, accessibility, land stability, and environmental risk factors, these projects face the challenge of providing quality, well-equipped public spaces, considering their potential for promoting social encounters and public life.

Projects have to deal with daunting soil and topographic conditions, local existing urban and architectural morphologies, and the availability of land in order to generate a well-articulated final environment-an environment where all residents have access to basic infrastructure and public spaces, services, and facilities, allowing their population to exercise neighborliness and reach full citizenship. Considering that slums are determined by historical, morphological, social, and local conditions (flood zones, hillsides, river banks, railroad rights-of-way, etc.), upgrading projects must be peculiar to each situation and are therefore necessarily different from one another. In addition, projects need to be widely discussed with the residents; cultural diversity is a relevant factor in defining architectural solutions.
In slum upgrading, a paved road system is designed to allow vehicular access for public services (ambulances, police, mail, waste collection) as well as for the installation of drinking water, sewage, and drainage systems. Dwellings in environmentally sensitive areas-such as flood zones and steep hillsides-are relocated, fragile slopes subject to landslides are contained, and streams are protected or channelized. Public equipment and spaces for parks, leisure, and recreation are defined as community centers, and guarantee the full development of activities that strengthen community relations.

Taking the city itself as a source of solutions, slum upgrading is mainly aimed at building quality public spaces that respect environmental and cultural pre-existences and that, above all, dilute the urban and symbolic boundaries between the formal city and its informally developed and marginalized areas. Slum upgrading and the integration of slums into the city by the provision of proper public infrastructure, facilities, and services multiply the residents' accessibility to work, education, and health, and encourage them to invest in improvements to their homes. Slum upgrading is a fundamental step toward contemporary urban life and full citizenship.

\section{São Paulo's Experience in Slum Upgrading}

The housing problem in São Paulo has been a challenge for decades. The city alone has almost 11 million inhabitants and 2,000 favelas where 800,000 families live, according to the 2010 Census. To face this huge challenge, the Municipality of São Paulo through the Municipal Housing Secretariat started one of Brazil's largest slum upgrading programs in 2005, with the understanding that such a program can alleviate poverty significantly, as noted above.

The program seeks to provide a better quality of life for those living in unsuitable areas and in slums across the city by basically overcoming a series of deficits related to infrastructure, accessibility, and availability of social amenities and public services, as well as the construction of new decent housing units. The municipal government respects and builds upon the great socioeconomic efforts made by these populations in building their dwellings, and works on restoring the quality of the space of each household and especially the quality of public space and its relation to each dwelling, and the formation of new neighborhoods and their integration to the city.

São Paulo's slum upgrading program can be regarded as a response to the 1988 Federal Constitution and the 2001 Statute of the City, which consolidated all citizens' right to the city and to decent housing, the social function of property, and the promotion of an equitable and just city through urban development. Public expenditures directed toward slum upgrading provide evidence of the Municipality's commitment to reverse the high level of social exclusion and to promote an inclusive process of sustainable urban growth.

Precarious housing-favelas or squatter settlements, slums, 
irregular subdivisions, and tenement houses-have been part of the urban landscape for a very long time. These are the only options available for families making less than three minimum wages per month - a sizeable segment of the populationsince their purchasing power is almost never compatible with the formal housing market. They can afford neither a dwelling unit nor a plot with proper infrastructure to build incrementally through self-help processes. The high price of development is mainly due to the lack of well-located land at compatible prices.

Another factor that helps exclude poor families from the formal market is the strict requirements created by zoning and building norms, which impose infrastructure, construction, and service standards that increase real-estate values significantly-pushing the low-income population even farther into the city's informal areas. Lacking capacity to access the formal housing market, the poor are left with no other alternative than to squat on public land-such as margins of rivers and railroad rights-of-way-and land of low commercial value that is usually disregarded by the formal development sector, such as areas in flood zones or subject to environmental risks-flooding, mud slides, contaminated soils, and landfillsor sites that are vacant due to judicial battles, such as lots with no heirs or that belong to religious orders.

The informal settlements are also a source of a great number of health problems, particularly those related to the lack of basic infrastructure, and social problems generated by this population's vulnerability, such as job informality, school evasion, early pregnancy, domestic violence, and drug trafficking.

In view of the complexity and dimension of this reality, elaborating a housing policy for the city is a very difficult task. It is necessary to know, in detail, all the problems to be faced, and to seek to quantify and to qualify the real needs that will guide the most consequential actions. Since 2005, the Municipality's housing policy has been committed right from the start to the search for the most adequate solutions; consequently, one of the first actions was to quantify and qualify the real needs, which guide ongoing actions. The policy seeks to understand each one of the low-income occupancies in its entirety, but also in its specificities, be it a slum, an irregular subdivision, a tenement house, or a deteriorated housing estate.

It is also necessary to evaluate the resources required to invest in each one of the housing programs, and to choose those that allow the optimization of public investment and benefit the largest number of people among the most needy who require housing solutions. There are neither magical solutions nor easy discourses; the housing issue is impacted by facts and statistics, and therefore requires a continuous, serious, and long-term policy. Due to the dimension of the housing problem, it is necessary to count on partnerships with state and federal governments, if only because suitable housing for all is a concurrent attribution of the three levels of government, as defined in the Brazilian Constitution (1988).

The actions of the administration are governed by the Federal Constitution that protects the individual's dwelling (Article 5 , Item XI) and regards habitation as one of the individual's basic needs (Article 7, Item IV), as is the right to education and health care. The Constitution also recognizes the competence of the Union, State, and Municipal governments respective to implementing housing policies and programs (Article 23, Item IX). Most importantly, it defines that a property's social function is above the individual's right to use it as he/she pleases.

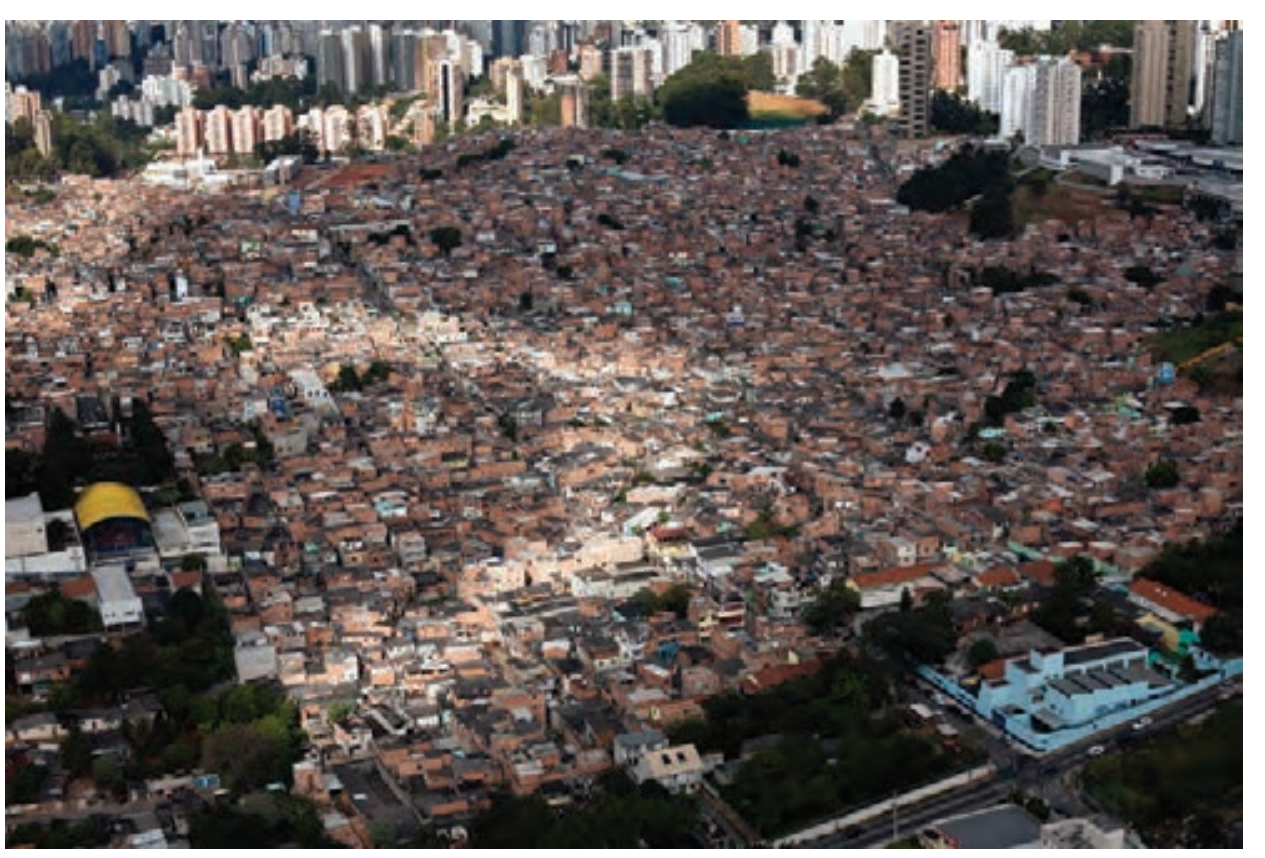

Figures 2 \& 3: Favela Paraisopolis, with an estimated population between 80,000 and 100,000 people; one of the settlements that benefited from the city's new housing programs. Floods were common before upgrading and the new infrastructure.

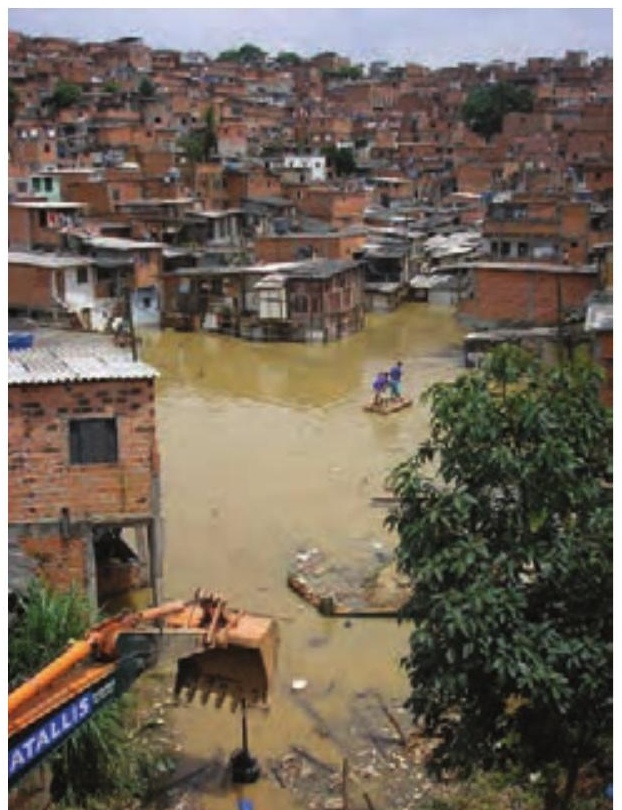




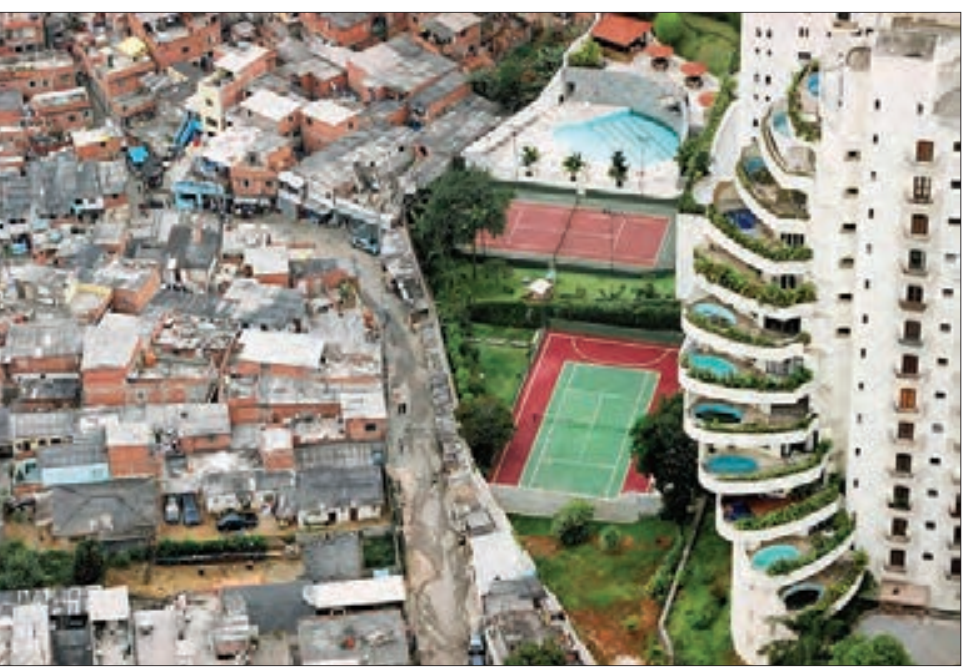

Figure 4: The sharp contrast between Paraisopolis and the luxury gated communities around it. (photo by Tuca Vieira; source: http:// www.tucavieira.com.br/A-foto-da-favela-de-Paraisopolis)

Moreover, in regulating the constitutional provisions regarding urban development, the Statute of the City, a Federal law of 2001, defines several new land-use and development control mechanisms that can be used by municipal governments to fulfill these provisions, particularly in regard to observing the social function of property.

São Paulo's housing policy complies with the city's 2002 Strategic Master Plan (PDE; Law 13.430, Article 79) that ratifies the Federal Constitution and recognizes the right to suitable housing as a social right. In the Strategic Master Plan, suitable housing is that which not only guarantees the resident's safety within it but also "provides adequate sanitary facilities, that guarantee the conditions of habitability, and that is met by essential public services, among them: water, sewage, electric power, public lighting, waste collection, pavements and public transport, with access to basic social equipment" (Strategic Master Plan, Article 79).

As a signatory of the Millennium Development Goals set by the United Nations, São Paulo seeks to attain a series of objectives established therein by the year 2020, especially in regard to increasing the number of families that have access to drinking water and other basic infrastructural needs, and to improving the general quality of life of families living in slums. The challenge is that the construction of the city must be based on the understanding and management of differences, in the search for social inclusion and the pro-active involvement of the communities in institutions at all government levels, and in civil society. This is how a democratic city should be constructed.

Based on the principles discussed above, São Paulo's city administration defined its housing policy and developed the largest slum upgrading program undertaken in the country: 130,000 families were benefited by works in progress or already concluded, with the final phase being providing the families with a deed to their land through granting a special use concession for living purposes. These slums became new neighborhoods added to the city, and families obtained an important part of their citizenship.

In addition to the upgrading - or "urbanization" in Portuguese-projects, including putting in the infrastructure to raise the health standard, 10,000 housing units are being built in order to replace dwellings located in risk areas. Among ongoing works and infrastructure installation contracted from 2005 to 2012, investments by the program totaled US\$ 3 billion. In order to continue this set of actions, funds from the municipal budget for housing were increased, augmented by funds from the State and Federal governments.

\section{A Brief Account of the Upgrading Process}

\section{Design}

A detailed diagnosis of each area is carried out prior to the execution of each project. Considering the highly "organic" and informal characteristics of these squatter settlements, project design has to adapt to each peculiar situation: Topographical conditions, the existing urban and architectural morphology, and the availability of land are fundamental factors. The elimination of risk is also a priority in upgrading squatter settlements, since many of them are prone to disasters because they occupy steep slopes subject to landslides, banks of creeks and flood zones, or other types of environmental factors.

Design solutions are based on the identification of a community's characteristics, their demands and expectations, and are widely discussed with residents. In all projects, a paved street network is designed to allow for vehicular traffic and access for public services, water supply, piped sewage, and drainage systems. Projects also have to respond to the lack of spaces for public amenities and social interaction. Public amenities and spaces for parks, leisure, and recreation are seen as strategic areas in the design because they strengthen social relations in the community. The new streets together with the new public spaces help create an articulated whole, making these settlements more accessible, coherent, and legible.

\section{Implementation}

One of the particularities in working with a process toward the upgrading of squatter settlements is the fact that it occurs in densely populated areas with precarious and difficult access. In many cases, normal construction equipment and machinery simply cannot be used, and low-cost solutions have not always been adopted since they are not always the most appropriate solution for each particular case. Professionals responsible for design and project implementation must be creative and find alternative solutions, adapting methods and standards to reality.

On the other hand, priority has to be given to works in areas of geological risk and difficult access, as well as to the construction of new housing for the families that will have moved from these 
and the settlement processes-and the management of data on housing units and households. The mechanism is enriched with GIS tools that increase possibilities for interpreting the data. The slums are characterized by identification data, occupation conditions, and urban, social, and legal infrastructure. From a base map, the system automatically calculates new data based on information from other registered maps; for instance, geographical indicators of occupation and the conditions of the urban infrastructure, using maps of the road network, hydrology, and sanitation.

In 2009 the system was improved through the application of a new integrated intervention model by hydrographic sub-basins, allowing us-in an unprecedented manner-to establish priorities based on the level of socio-environmental risk indicators of each sub-basin. This work resulted in a new map of the city of São Paulo, revealing the environmental factors and risk levels in all its territory for the first time. This map follows the water basins, going beyond the official municipal and state administrative boundaries that traditionally impeded tackling environmental issues comprehensively. Indeed, only when we treat the territory seamlessly can we obtain real environmental sustainability indexes, reflecting what the world's major cities have embraced through the C40 Cities Climate Leadership Group and the Millennium Development Goals. ${ }^{6}$ At that time we also began preparing the Municipal Housing Plan's long-term goals, which were distributed over four four-year periods (2009 to 2024), considered the period of time necessary to achieve a minimum reduction in the rates of insecurity from environmental threats in the city of São Paulo. ${ }^{7}$

We also prepared the Regional Action Plans (RAPs) based on the limits set by the hydrographic sub-basins, the amount of precarious settlements in each and their population, and the homes that were settled in risk areas. Inside the RAPs, the Perimeters of Integrated Action (PAls) were defined and adopted as planning units to guide interventions by SEHAB (Secretary of Social Housing). Each PAI congregates a series of slums within a single perimeter, so that interventions can be planned not in isolation but in an integrated manner; the number of new housing units needed as well as all the costs in each intervention can be better predicted and quantified.

In March 2010, during the United Nation's 4th World Urban Forum in Rio de Janeiro, after five years of uninterrupted work involving SEHAB's entire team-supported by a set of specific studies prepared by consultants-the City of São Paulo's Municipal Housing Plan was presented to the public. ${ }^{8}$ The plan

\footnotetext{
${ }^{6}$ The C40 Cities Climate Leadership Group (C40) is a network of the world's megacities committed to addressing climate change. See $<$ www.c40cities.org>

${ }^{7}$ The four-year periods coincide with political mandates at the municipal level.

${ }^{8}$ Both English and Portuguese versions of São Paulo's Municipal Housing Plan are available for downloading from <http://www. habisp.inf.br/doc/category/pmh >
}

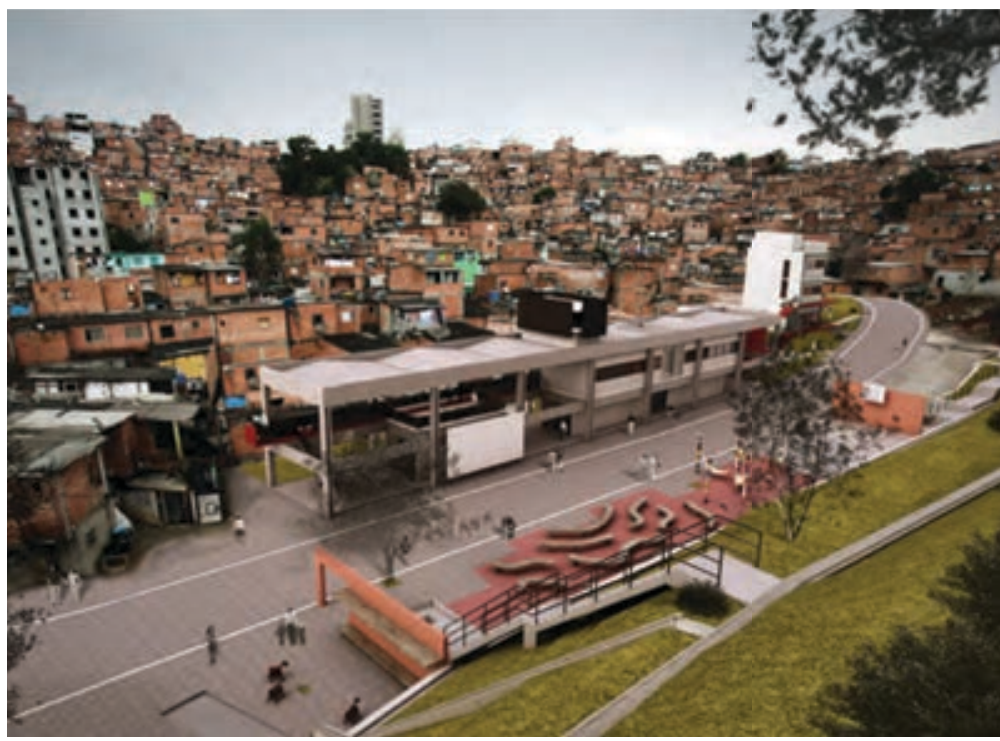

Figures 6 \& 7: Public facilities in Paraisopolis. A community center built in a valley (above) and a recreational facility in left-over spaces (below).

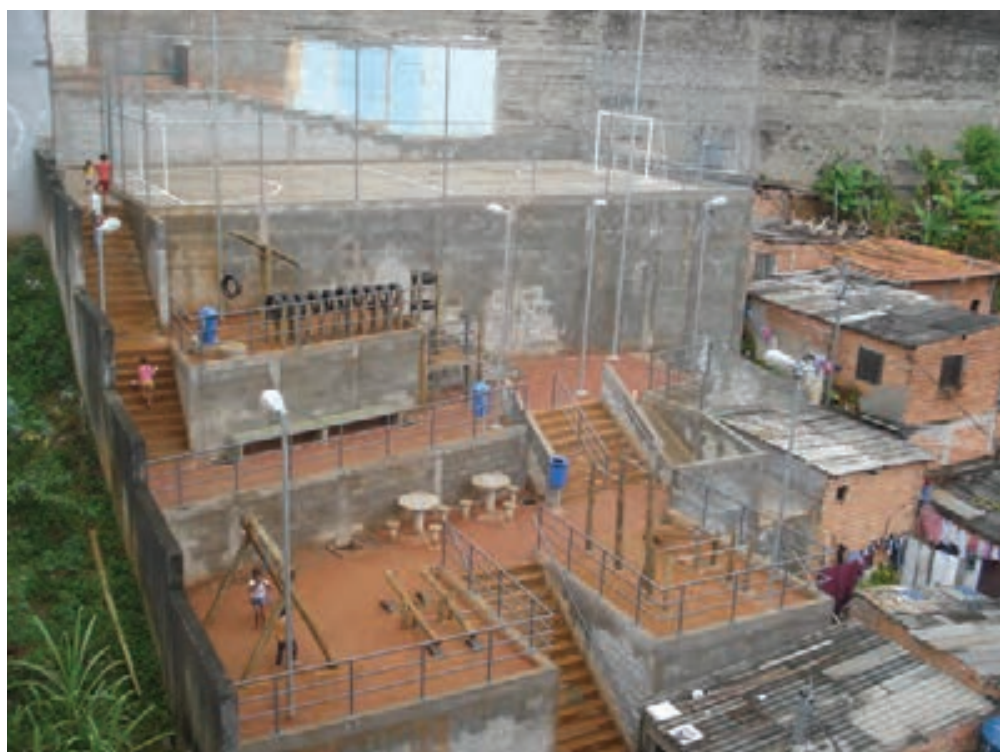

is based on the implementation of five general principles: a) the right to decent housing; $b$ ) social justice; $c$ ) environmental sustainability as a right in the city; d) democratic governance; and e) efficient management of public resources. It recognizes the Habisp information system as a guide to prioritize interventions as well as the need for a comprehensive territorial approach, and describes eight housing programs for different housing problems and types of communities for the attainment of specific goals.

\footnotetext{
${ }^{9}$ For details on the competition and the winning projects, see <http://renovasp.habisp.inf.br/concurso/info/apresentacao>
} 
Just to briefly mention some of the results obtained: in the four largest favelas, as a result of the Slum Upgrading Program, all households are now served by piped drinking water and sewage collection serves 80 percent of them, 3,000 new residential units were built for families who were exposed to risk, creeks were channelized, and recreational and public facilities such as schools, daycare centers, and health units were built and are fully operational.

The new policies guided SEHAB in preparing projects to upgrade larger settlements. So far, plans have been made for Jardim São Francisco, Heliópolis, Paraisópolis (Figures 2 to 7), and for the PAls of the Cabuçu Basin, and soon will be expanded to the Serra da Cantareira region and the Pirajussara Basin. These plans' first stage was the construction of pilot neighborhoods, on a scale that allowed the population to express their concerns-pointing out the problems, and making proposals for specific interventions related to infrastructure, deployment of equipment, recreation areas, and vehicular connections, among others. Note that a special emphasis must be given to the establishment of forums for leaders and their participation in the development and revision of the plans and projects.

We learned that a master plan is an essential part of the development of projects for the PAls, since it allows a comprehensive view of an area, the integration with other disciplines and city sectors, and the building of scenarios ranging from the highest priority actions under the Municipal Social Housing Secretary to those that fall under joint responsibility with other city agencies and secretaries.

In 2011 the city signed a partnership with the Institute of Architects of Brazil (IAB-DN) for the Renova SP Program, based on a national public competition for urban and architectural projects for twenty-two PAls that resulted in contracts with seventeen design firms. ${ }^{9}$ All projects follow the municipal housing policies and approach, respecting preexistences, the life history of residents, the investments they have made in building their homes and the community infrastructure and, most importantly, the existing social networks. Renova SP's biggest challenge lies in its universe of 80,000 households, meaning that the designers have to involve the participation of each PAI in the process, making sure they meet community expectations, demands, opinions, and desire to see their settlement transformed into a real neighborhood and become an integral part of "formal" São Paulo.

In 2012 SEHAB published a set of very complete urban planning and design guidelines, organized around strategies at the street, neighborhood, and city levels. These principles deal with, for example, "active street-fronts and to avoid walls", "closing gaps between buildings and active streetscape", "put

\footnotetext{
10 See SEHAB's "From Plan to Projects: New Neighborhoods and Social Housing in Sao Paulo", available from <http://www.habisp.inf. $\mathrm{br} / \mathrm{doc} /$ category/pmh >
}

pedestrians first with comfortable sidewalks", "reorganize street network to facilitate traffic flow but prioritize walking", "reducing urban heat islands", "storm water detention", "bury infrastructure", "shared streets and traffic calming", etc. ${ }^{10}$

\section{Final Remarks}

The completion of Renova SP was an important step in implementing São Paulo's Municipal Housing Policy (MHP). As we saw above, the MHP incorporated SEHAB's new approach to public policies and design, based on the ability of public officials and on incorporating the lessons from several experiments, such as the UN Habitat's best practices. The world today allows for easy and rapid sharing of ideas, contributing to the advancement of human knowledge.

Also, over the past few years, SEHAB developed a series of partnerships with educational institutions, specialists, and architecture firms, as well as local and international professional and research groups. These collaborations contributed to SEHAB's work, which consequently grew and expandedbecoming a world reference for countries and cities facing similar problems. A recognition of this success was the Scroll of Honours Award received by the Slum Upgrading Program from the United Nations Habitat during the 5th World Urban Forum, in September 2012.

Another recent recognition was the recent award given to the project for Parque Cantinho do Céu, a slum with 10,000 families located in the margins of the Billings water reservoir. ${ }^{11}$ Part of the Guarapiranga water basin environmental program mentioned above, this project is an excellent example of an urban design solution that is perfectly integrated with environmental upgrading (Figures 8 and 9). It was appointed as one of ten projects to represent Brazil in the 2013 LatinAmerican Architectural Biennial in Pamplona, Spain.

It is always important to remember that our object of concern is the city and its new neighborhoods that are being built every day; precariously, devoid of proper infrastructure, and with extremely low levels of environmental quality. We no longer conceive of the existence of a formal city that is legal, and another that is informal and built outside the law. We can no longer see slums as sub-normal buildings that need to be evicted, but as communities that have invested their lives and savings in securing a space in the city, in the only locations to which they had access. Their social networks have allowed them to survive the hardships of their daily lives and represent the greatest wealth of their settlements. These communities are building the true contemporary city, albeit lacking the mechanisms to access proper land tenure, housing, public facilities, and educational and economic opportunities.

\footnotetext{
${ }^{11}$ Project by Boldarini Arquitetura e Urbanismo. See < http://www. arcoweb.com.br/arquitetura/boldarini-arquitetura-urbanismo-parquepublico-19-01-2011.html>
} 
Gradually São Paulo's government began reassessing priorities, focusing on the real housing problems, and responding to the demands of communities that are better organized. In recent years SEHAB has worked hard with these neighborhoods and their residents. The work culminated in the completion of the Municipal Housing Plan, the Renova SP Competition, and the Urban Planning and Project Guidelines. In 2005 when we started reorganizing SEHAB and working on the housing policies, we envisaged some paths and outcomes. Today it is possible to say that São Paulo's municipal housing policy is a source of pride for those who worked on it. Above all, it is a legacy that should be seen as a best practice in public policy.

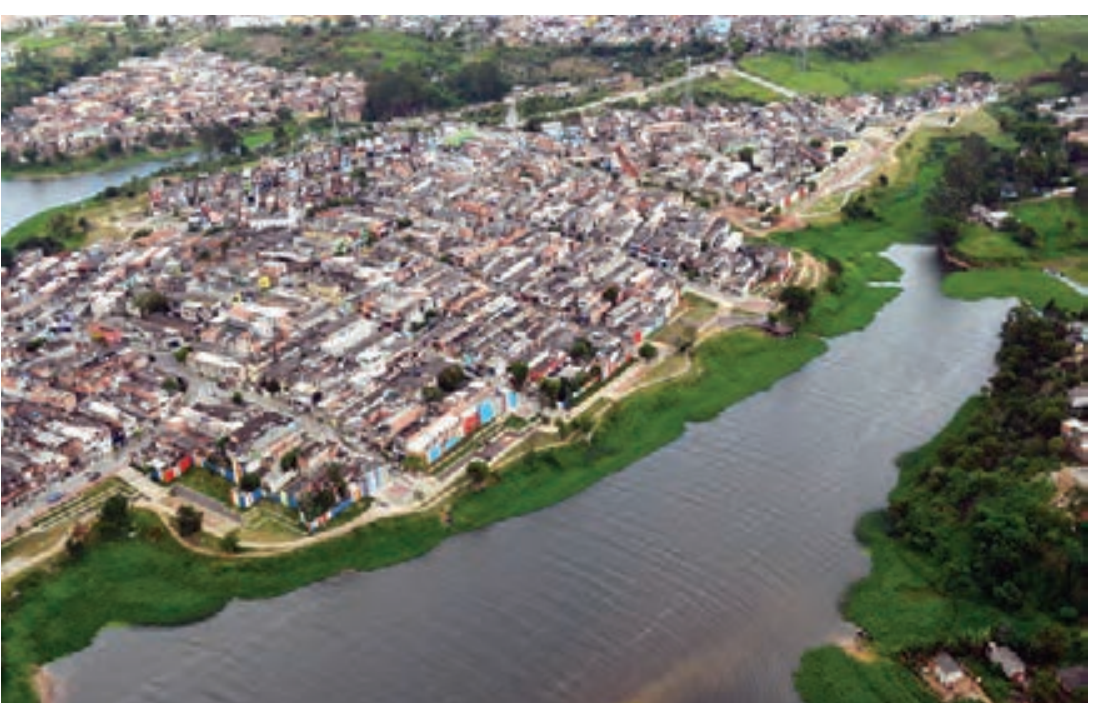

Figures 8 \& 9: Aerial view and site plan of Parque Cantinho do Céu, in the margins of Billings water reservoir. Integration of environmental planning, physicial upgrading, and urban design. By Boldarini Arquitects, São Paulo.
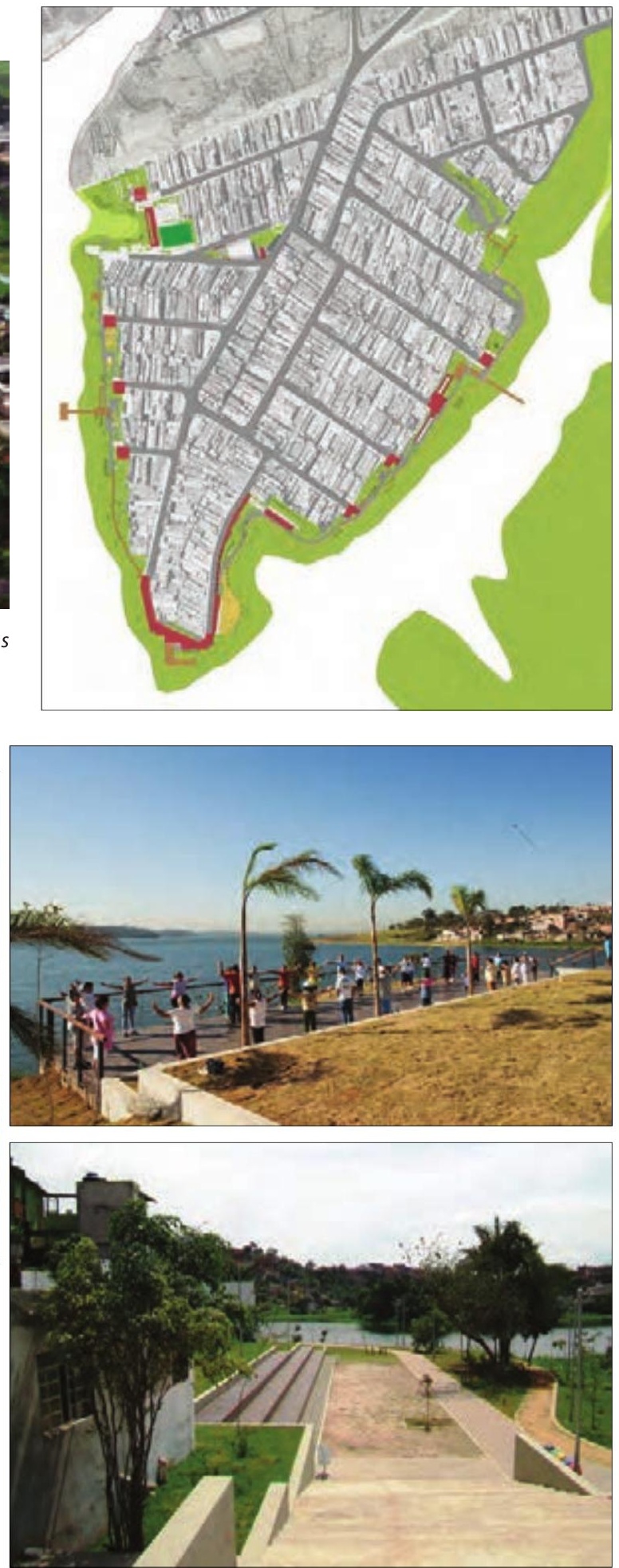